JOURNAL OF SECURITY AND SUSTAINABILITY ISSUES

ISSN 2029-7017 print/ISSN 2029-7025 online

2020 September Volume 10 Number 1

https://doi.org/10.9770/jssi.2020.10.1(6)

Scopus

\title{
STATE MANAGEMENT IN THE AREA OF ENSURING THE SECURITY OF THE COURT AND PARTICIPANTS IN LEGAL PROCEDURES
}

\author{
Vadym Kolomiiets $^{1 *}$, Tetiana Lukianenko², Daria Lazareva ${ }^{3}$, Nana Bakaianova ${ }^{4}$, Oksana Kadenko ${ }^{5}$ \\ ${ }^{1 * 2,3}$ Sumy National Agrarian University, Gerasim Kondratieva Street, 160, Sumy, 40000, Ukraine \\ ${ }^{4,5}$ National University “Odessa Law Academy”, Fountain road, 23, Odessa, 65000 Ukraine \\ E-mail: ${ }^{1 * k o a d u e p @ g m a i l . c o m ~(C o r r e s p o n d i n g ~ a u t h o r) ~}$
}

Received 12 December 2019; accepted 25 May 2020; published 30 September 2020

\begin{abstract}
The authors investigated the features of the legal regulation of the functioning and organizational aspects of the activities of the authorities, the competence of which includes ensuring the security of the court, judges, and other participants of legal proceedings. Particular attention is paid to the intergovernmental body of the Council of Europe - The European Committee on Legal Co-operation (CDCJ), one of the activities of which is to ensure the proper functioning of the judiciary. The features of the general project between the CDCJ and Ukraine "Support for judicial reform in Ukraine (voluntary contribution)" are identified. The features of the activities of sheriffs in Canada and the USA, the regulatory documents of these countries, which determine the status and competence of the sheriffs in the field of judicial protection, are highlighted. The chronology of the establishment in Ukraine of the state system for protecting the court, judges, and other participants of legal proceedings, from 1997 to the present, is investigated. In the course of the study, the authors have been determined the individual stages of the establishment in Ukraine of the state system for protecting the court, judges, and other participants of legal proceedings; the competence of state bodies to ensure judicial protection and the legal basis for their activities, depending on the period of operation. The content of the norms of some regulatory legal acts of Ukrainian legislation, which regulates the activities of the bodies responsible for ensuring the security of the court, judges, and other participants of legal proceedings, is disclosed. The scheme of "gap" while elemental situational analysis of safety of participants in legal proceedings is examined. A matrix for ranking the factors of complex security of participants of judicial system and recommendations on development of public management in the area of legal and judicial security.
\end{abstract}

Keywords: state management; protection management; socio-economic system; court; independence of judges; immunity of judges; sheriff; Judicial Protection Service of Ukraine

Reference to this paper should be made as follows: Kolomiiets, V., Lukianenko, T., Lazareva, D., Bakaianova, N., Kadenko, O. 2020. State management in the area of ensuring the security of the court and participants in legal procedures. Journal of Security and Sustainability Issues, 10(1), 73-89. https://doi.org/10.9770/jssi.2020.10.1(6)

JEL Classifications: F35; F42

\section{Introduction}

Secure and sustainable development of any country depends on many factors, alas legal framowork, as almost uninoulsly agreed, appears to be one of the most important pillars of many ebraced phenomena (Kuril, 2018; Sitdikova, Starodumova, 2019; Prause et al., 2019; Kordík, Kurilovská, 2019; Stefaniuk, 2020; Chehabeddine, Tvaronavičienè, 2020; Lincényi, Čársky, 2020).

Court protection of human and civil rights and freedoms of Ukraine is guaranteed at the constitutional level (Article 55 of the Constitution of Ukraine). Thus, the state plays a decisive role in ensuring the human right to fair, effective, and high-quality justice. In order to properly ensure the implementation of legal proceedings, it is important to observe the principles of independence and inviolability of judges provided for in Articles 126 
and 129 of the Basic Law (Constitution of Ukraine, 1996). The independence and inviolability of judges is a guarantee of the independence of the judicial branch of power in the country as a whole and a condition for an effective system of judicial protection of the rights and legitimate interests of a person and citizen in particular.

Art. 130 of the Constitution of Ukraine, the state is under an obligation to provide funding and proper facilities for the functioning of the courts and the activities of judges (Constitution of Ukraine, 1996). The effectiveness of the mechanism for implementing the specified constitutional order in practice is determined by the state of legal and organizational support of the activities of the court, judges, and the entire judicial process. The content of the definition "judicial protection" covers a number of activities, including the protection of organs and institutions of the justice system; security of court premises and adherence to access control; ensuring personal security of both judges and members of their families, as well as other court employees; ensuring the security of other participants of legal proceedings.

The creation of the Judicial Protection Service in Ukraine was aimed at ensuring the security of the court, the personal security of judges and members of their families, as well as other participants of legal proceedings. Today, the process of forming such an organ is incomplete to the end. Therefore, it is relevant to study the legal and organizational aspects of its creation (including the competitive selection of candidates for vacant positions), determine the internal structure, and disclose the features of the activities of this state body.

\section{Literature Survey}

In the context of the subject under study, it is important to study the international experience in the legal regulation of the functioning and organizational aspects of the activities of the authorities, which are responsible for ensuring the security of the court, judges, and other participants of legal proceedings. This applies in particular to the protection of organs and institutions of the justice system; protection of court premises and compliance with access control; ensuring personal security of both judges and members of their families, as well as other court employees; ensuring the security of other participants of legal proceedings.

To date, since 1963, an intergovernmental body of the Council of Europe, the European Committee on Legal Co-operation (CDCJ), has been operating in the European space. The CDCJ is responsible for the proper functioning of the judiciary, for setting standards for the Council of Europe with broad competence in public and private law. Its main role is to develop standards generally accepted by 47 member countries and to promote legal cooperation among them. The members of the CDCJ, as representatives of the Ministry of Justice, are particularly well-placed in the Organization to provide the necessary national communication between the government and the judiciary (About the European Committee on Legal Co-operation).

Judicial independence and impartiality are one of the priority areas of the CDCJ's ongoing activity. It was the CDCJ that prepared Recommendation CM/Rec (2010) 12 on judges: independence, efficiency and responsibilities, approved by the Council of Europe on November 17, 2010. It is important to note that Recommendation $\mathrm{CM} / \operatorname{Rec}(2010) 12$ is based on the principle of independence and impartiality of judges, which is primarily determined by Art. 6 of the Convention for the Protection of Human Rights and Fundamental Freedoms of November 4, 1950. The requirement of the said norm provides for the guarantee to every person of his or her fundamental right to the resolution of his or her case by a fair trial only on legal grounds and in the absence of any undue influence (Convention for the Protection of Human Rights and Fundamental Freedoms, 1950).

Recommendation CM/Rec (2010) 12 states that the independence of individual judges is protected by the independence of the judiciary as a whole, and therefore this is a fundamental aspect of the rule of law. Judges should have unlimited freedom to decide cases impartially, in accordance with the law and their interpretation of the facts. The independence of the judge and the judiciary should be consolidated at the highest level of legislation (constitutional level) in member states, with more specific rules provided for at the legislative level. In the event of a threat to independence, judges should be able to either turn to the judicial board or another independent authority, or have effective remedies (Recommendation CM/Rec (2010) 12, 2010). 
The issue of judicial protection is defined in II chapter of Recommendation CM/Rec (2010)12 under the name "External independence". In particular, it is noted that the external independence of judges is not at all their privilege or prerogative. On the contrary, the independence of judges is ensured in the interests of the rule of law and those who seek and expect impartial justice. The independence of judges should be seen as a guarantee of freedom, respect for human rights, and the impartial application of the rule of law. Respect for the principles of impartiality and independence of judges is an essential guarantee of equality of arms before the courts (Recommendation $\mathrm{CM} / \operatorname{Rec}(2010)$ 12, 2010).

Among the 12 measures proposed in Recommendation CM/Rec (2010) aimed at upholding the principles of independence and impartiality of judges, it is important to note the following ones:

(1) taking all necessary measures to respect, protect, and promote the independence and impartiality of judges;

(2) legislatively sanctioning individuals who try to influence judges inappropriately (Recommendation CM/ $\operatorname{Rec}(2010)$ 12, 2010).

Thus, taking into account the requirements of Recommendation CM/Rec (2010) 12 , it is necessary to determine the following responsibilities assigned to the executive and legislative powers of member states:

(1) guarantee of the independence of judges;

(2) preventing actions that could undermine the independence of the judiciary or public trust in it;

(3) prosecution of persons trying to influence judges incorrectly.

In 2015, according to the results of the second report of the Secretary General of the Council of Europe on the state of democracy, human rights, and the rule of law in Europe, special attention was paid to the lack of judicial independence in many European countries, one of the biggest challenges to a democratic society. The standards of impartiality and independence have been recognized as insufficiently guaranteed. The identified problem was the impetus for the Council of Europe's elaboration of an Action Plan on "Strengthening the independence and impartiality of the judiciary" in order to support member states in taking such measures.

The Council of Europe Action Plan was adopted by the Committee of Ministers on April 13, 2016. The implementation of the measures will start on April 21-22, 2016 at the High-Level Conference of Ministers of Justice and Representatives of the Judiciary, held in Sofia (Bulgaria) (Judicial independence and impartiality).

Among the measures identified by the Action Plan, the adoption of which may provide protection for individual judges, it is important to note the following ones:

(1) to provide for effective protection tools for judges in whose opinion their independence and impartiality are at risk;

(2) to ensure that judges are protected by legal norms and adequate measures against attacks on their physical or mental integrity, their personal freedom and security (Plan of action on strengthening judicial independence and impartiality, 2016).

It is important to emphasize that the activities of the CDCJ are also related to the implementation of joint projects with member states of the Council of Europe. Ukraine entered the list of member states back in 1995 after the adoption of the Law of Ukraine "On Ukraine's Accession to the Statute of the Council of Europe" dated October 31, 1995 (Law of Ukraine No. 398/95-VR, 1995).

To date, according to the information posted on the CDCJ's official website, two joint projects have been introduced with Ukraine, one of which is "Support for Judicial Reform in Ukraine (voluntary contribution)". The project is being implemented in Ukraine in cooperation with Ukrainian colleagues - the Judicial Reform Council, the Supreme Court, the High Council of Justice, the High Qualification Commission of Judges of Ukraine, the Council of Judges of Ukraine, and others. The project is led by the Department of Justice and Legal Cooperation of the General Directorate for Human Rights and the Rule of Law. The project aims to support Ukraine in completing judicial reform and in implementing the adopted legislation in order to ensure the independence, 
fairness, and effectiveness of the judiciary, in accordance with the standards and recommendations of the Council of Europe. The project implementation period is 30 months: (from June 1, 2018 till November 30, 2020), and the budget is 1,200,000 euros. The objectives of the project are:

(1) supporting Ukraine in the development of national legislation on the judiciary and improving compliance with standards of the Council of Europe;

(2) review and monitoring of the functioning of the judicial institutions, taking into account their new and changed powers, compliance with standards of the Council of Europe and similar European practices;

(3) supporting the National Bar Association of Ukraine and other national bar organizations in the creation of a bar association in accordance with Council of Europe standards and European best practices.

Among the expected results can be seen:

1. Amended legislation in Ukraine will allow the judiciary and law practice to adhere to standards of the Council of Europe.

2. The functioning of the courts and judicial institutions within the framework of the reformed legislative framework is in line with Council of Europe standards and relevant European practices.

3. The involvement of the bar in litigation in terms of procedure and practice is consistent with the standards of the Council of Europe (Support to the judicial reform in Ukraine).

The protection of the court, judges, and other participants of legal proceedings in many countries of the world is usually carried out by law enforcement agencies. Compliance with the principle of independence of the judicial branch of the government presupposes precisely the inadmissibility of pressure and threats from third parties, which may ultimately negatively affect the adoption of a judicial decision in a particular case. For example, in Canada, the security of the court and participants of legal proceedings is within the competence of the Canadian County Sheriff's Office. The Sheriff's Office administration includes Sheriff, Undersheriff, Majors, Finance Manager, and Sheriff's Secretary. All Sheriff's Office employees are appointed by Sheriff. In particular, to oversee daily operations, Sheriff appoints Undersheriff.

The Sheriff's Office Citizencourt Office is both full-time and part-time. In addition to the duties entrusted to representatives of the patrol service, civil servants support the safety and order of the court. They are responsible for the daily security of all judges, lawyers, employees, and citizens passing through the doors of the court. Every year, approximately 35,000 people go through the examination process in the courthouse. The Sheriff's Office civil servants are responsible for:

(1) all prisoners who enter and leave a judicial institution

(2) staying with prisoners throughout the legal process and ensuring the safety of the courtroom;

(3) ensuring the protection and safety of all legal proceedings, as well as the legal process;

(4) court security at night and on weekends;

(5) arrests made in the course of proceedings under warrants or any violation or request to court (The official website of the CCSO).

The selection criteria for Sheriff's Office employees are as follows: ability to work in a team, initiative, decency, integrity, self-control, ability to manage conflicts, willingness to learn throughout life, and devotion to the interests of the organization. As a result of the interview, candidates may receive a preliminary offer on a post for further examination or a job placement. In turn, sheriffs with a certain length of service must undergo training to improve their qualifications, and include testing physical fitness, weapons skills, monitoring the use of force, and communication skills. The Canadian court security system model is efficient and progressive (Savilova, 2019).

In the United States, judicial protection is also the responsibility of sheriffs. County Sheriff's Departments operate in each state. Let's look at the example of Los Angeles County Sheriff's Department. What are the features of the activities of sheriffs in the field of judicial protection? The Sheriff's Court Services Division is responsible for the safety of all state courthouses. Judicial protection is carried out in three areas, namely: 
(1) Court security. All persons and their property are subject to inspection before entering the court, as well as in the case of re-entry into the judicial institution. Guards supervised by the Sheriff peace officer supervisor use metal detectors for inspection, which ensures the overall security of the court. Weapons of any kind are confiscated, and the owner for the possession of weapons is arrested in the courthouse. It is forbidden to carry with you any items that could potentially be used as a weapon. As well, it is prohibited to take any sharp objects (for example, scissors) to the court, so they are left in storage and then returned to the owner. A corresponding document is issued for all items remaining at the entrance for storage.

(2) Courtroom security. Deputy sheriffs act as bailiffs and maintain order in courtrooms. Any person who violates the procedure for a court hearing should be expelled from the courtroom and/or arrested. All photographing, recording, and television production in the hall must be approved in writing.

(3) The security of prisoners. Deputy sheriffs keep the accused (defendants) in specially designated places. It is not allowed to visit prisoners in the courthouse (The official website of the Los Angeles County Sheriff's Department).

Regarding the training of sheriffs in the field of judicial protection, it is important to note that since 1940 the National Sheriffs' Association (NSA), a professional association, has been working with the Office of Sheriff and its affiliates by providing law enforcement education and training, as well as general information resources. For many years, the NSA has been conducting programs for sheriffs, their deputies, police chiefs, and others in the field of criminal justice aimed at enhancing the professional activities of their work. NSA is headquartered in Alexandria, Virginia state, and offers sheriffs a wide range of programs, including security training in court (The official website of the NSA).

In the field of judicial protection, the Institute of Judicial Security offers specialized training in the following areas:

(1) Court \& Judicial Security Certification. In order to ensure the safety of judges and all who are members of a judicial institution, staff should be adequately trained. The NSA, in collaboration with the Texas A \& M Engineering Extension Service (TEEX) Corrections Academy, provides training opportunities for staff.

(2) NSA Court Security Training. The NSA has long been providing education to maintain court security and protect the court working group, citizens, and users of the judiciary.

(3) Court Security Assessments. NSA's Court Security Assessment assists in the identification and development of the accountability and security practices of the court (The official website of the NSA).

\section{Methods}

In order to study the peculiarities of the legal regulation of the functioning and organizational aspects of the activities of the bodies whose competence includes ensuring the safety of the court, judges, and other participants of legal proceedings, historical, formal-legal, and system-structural methods have been applied.

When using the historical method, the chronologic of the establishment in Ukraine of the state system for protecting the court, judges, and other participants of legal proceedings, from 1997 to the present, has been investigated.

When using the formal-legal method, the contents of the norms of certain regulatory legal acts (documents) are disclosed that regulate the activities of bodies whose competence includes ensuring the security of the court, judges, and other participants of legal proceedings. In particular, the legal framework that defines the legal status of the Judicial Protection Service of Ukraine, tasks, principles of activity, organizational structure of this state body, powers, monetary and social security of employees, etc., contained in a number of regulatory legal acts are highlighted. Also, when studying the features of judicial protection in Canada and the United States, special attention is paid to the regulatory documents of these countries, which determine the status and competence of sheriffs. 
The system-structural method was used to determine the individual stages of the establishment in Ukraine of the state system for protecting the court, judges, and other participants of legal proceedings; the competence of state bodies to ensure judicial protection and the legal basis for their activities, depending on the period of operation.

\section{Results}

The activities of bodies whose competence includes ensuring the safety of the court, judges, and other participants of legal proceedings, require proper legal consolidation in the relevant legislative and departmental regulatory acts. In Ukraine, the first step in this direction was the adoption of two laws at once on December 23, 1993: "On state protection of court and law enforcement officials" and "On ensuring the safety of persons participating in the criminal process".

The Law of Ukraine "On State Protection of Court and Law Enforcement Employees" established a system of special measures of state protection for judges of the Constitutional Court of Ukraine, judges, and court staff from obstructing the fulfillment of their duties and the exercise of the rights granted, as well as encroachments on life and health, housing and property of these persons and their close relatives in connection with the official activities of these persons (Law of Ukraine No. 3781-XII, 1993).

In its turn, the Law of Ukraine "On ensuring the safety of persons participating in criminal proceedings" determined that ensuring the safety of persons participating in criminal proceedings is the implementation by law enforcement bodies of legal, organizational, technical, and other measures aimed at protecting life and housing, health, and property of these persons from unlawful attacks, in order to create the necessary conditions for the proper administration of justice. The law requires bodies that ensure security, respect for the rule of law and respect for the rights and freedoms of citizens. The rights of bodies implementing security measures include:

(1) determination of security measures, means, and methods of their application, if necessary, to amend and supplement these measures;

(2) to demand from persons taken under protection the observance of the conditions for the implementation of security measures, as well as the execution of legal orders related to the application of these measures;

(3) to apply to the investigator, prosecutor, court in the process of criminal proceedings with a petition for a decision on the application of security measures in the course of procedural actions or on the cancellation of measures taken.

The responsibilities of the organs that ensure safety include:

(1) an immediate response to each case of unlawful committed in connection with their assistance in legal proceedings acts that they become aware of in relation to persons taken under protection;

(2) ensuring the protection of life, health, housing, and property in accordance with the nature of the threat;

(3) timely notification to the protected persons of the change or cancellation of their security measures (Law of Ukraine No. 3782-XII, 1993).

In the period from 1994 to 2000, a number of by-laws and regulations were issued in order to optimize the application of the rules defined by Laws No. 3781-XII, No. 3782-XII. So, by order of the Ministry of Internal Affairs of Ukraine dated July 23, 1997 No. 467, special police units were created in the structure of the public security police to ensure the safety of court employees, law enforcement agencies, persons involved in criminal proceedings, their families and close relatives. The order also provided for the approval of the Interim Regulation on this unit (Order of the Ministry of Internal Affairs of Ukraine No. 467, 1997).

In 2003, to ensure the security of court employees, law enforcement agencies, persons involved in criminal proceedings, members of their families, and close relatives and to protect forensic institutions of the main departments of the Ministry of Internal Affairs of Ukraine in the Autonomous Republic of Crimea, the city of Kyiv and the Kyiv region, departments of the Ministry of Internal Affairs of Ukraine in the regions and the city 
of Sevastopol, special police units were reorganized into special units of the judicial police "Hryfon". By order of the Ministry of Internal Affairs of Ukraine dated November 19, 2003 under No. 1390, the Regulation on this special unit of the judicial police was approved. Among the main tasks of this unit was the provision of security measures when considering court cases in all instances, employees of law enforcement bodies, and other bodies that exercise law enforcement or law enforcement functions, their family members and close relatives; taking the necessary measures to ensure the security of the judge, members of his or her family, the safety of their property, if a corresponding application is received from the judge, etc. (Regulations on the special unit of the judicial police "Hryfon", 2003).

With the adoption of the Law of Ukraine "On the National Police" dated July 2, 2015, the special unit of the judicial police "Hryfon" was liquidated in the system of internal affairs, which provided security for the premises, maintenance of public order in court, stopped manifesting disrespect for the court, and also performed functions of ensuring the personal security of judges and members of their families, court employees, and participants of legal proceedings. The final and transitional provisions of the Law of Ukraine "On the National Police" provided for amendments to some regulatory legal acts, in particular, to the Law of Ukraine "On the judicial system and status of judges". The changes concerned the creation of a corporate paramilitary judicial security. Departments of the corporate paramilitary security are formed by the State Judicial Administration of Ukraine in coordination with the Ministry of Internal Affairs of Ukraine, whose employees, while on duty, have the right to use firearms and special equipment in the manner and in accordance with the requirements defined by law. The state judicial administration, in agreement with the Ministry of Internal Affairs of Ukraine, approves the regulation on corporate paramilitary security and monitors the activities of its units (Law of Ukraine No. 580-VIII, 2015).

In accordance with the Decree of the Cabinet of Ministers of Ukraine "On ensuring the protection of courts, other bodies, and institutions of the judicial system, as well as institutions of forensic science" dated November 9, 2015 under No. 906, the protection of courts, other bodies, and institutions of the judicial system, as well as institutions of forensic examinations was carried out by units of the National Guard and National Police (Resolution of the Cabinet of Ministers of Ukraine under No. 906, 2015).

Pursuant to the requirements of the Law of Ukraine "On the Judicial System and the Status of Judges" dated June 2, 2016, by the Order of the Ministry of Internal Affairs of Ukraine dated December 26, 2016 No. 1352, the Temporary Order for the Protection of Courts, Bodies, and Institutions of the Justice System, as well as maintaining public order in them, was approved. The Temporary Order defines the mechanism for ensuring the protection of court premises, bodies, and institutions of the justice system, maintaining public order in them, which is carried out by units of the National Police of Ukraine and the National Guard of Ukraine temporarily, until the beginning of the full implementation of the powers of the Judicial Protection Service (Order of the Ministry of Internal Affairs of Ukraine No. 1352, 2016).

According to the Temporary Order, the units of the National Police and the National Guard were entrusted with the duties of:

(1) maintaining public order in court;

(2) termination of contempt of court;

(3) protection of courtrooms, bodies, and institutions of the justice system;

(4) performance of the functions of state provision of the personal security of judges and members of their families, court employees;

(5) protection of participants of legal proceedings (Temporary order, 2016).

Legislative consolidation of the legal status of the Judicial Protection Service of Ukraine took place with the adoption of the Law of Ukraine "On Amendments to the Law of Ukraine" On the Judicial System and Status of Judges "in connection with the adoption of the Law of Ukraine" On Higher Anti-Corruption " 
Legislative consolidation of the legal status of the Judicial Protection Service of Ukraine occurred with the adoption of the Law of Ukraine "On Amendments to the Law of Ukraine "On the Judicial System and the Status of Judges" in connection with the adoption of the Law of Ukraine "On the Higher Anti-Corruption Court" dated July 12, 2018 (Law of Ukraine No. 2509- VIII, 2018). The active process of creating this state body began in April 2019 with the adoption of the Regulation on the Judicial Protection Service.

In the Law of Ukraine "On judiciary and status of judges" dated June 2, 2016, the norms of Section XI the organizational support of the courts are regulated. In particular, the norms of Chapter 4 of Section XI are devoted specifically to determining the legal status of the Judicial Protection Service (hereinafter - JPS). According to Part 1 of Art. 161 of the Law, the JPS is a state body in the justice system, which serves to ensure the protection and maintenance of public order in the courts. The JPS is headed by the Chairman, who oversees the activities of this body. The appointment of the Chairman through open competition and its dismissal are assigned to the competence of the High Council of Justice. In the same way, the appointment and dismissal of the Vice-Chairmen are carried out according to the corresponding submission of the latter (Law of Ukraine No. 1402-VIII, 2016).

The organizational structure of the JPS involves the presence of a central governing body (JPS Central Office) and territorial units (JPS territorial departments). The Central Office of the JPS is a legal entity, which has a seal with the image of the State Emblem of Ukraine and its name, its own forms, independent balance, and accounts in the bodies of the State Treasury Service of Ukraine. The decision to establish territorial units of the Service is within the competence of the Head of the Service but necessarily requires the approval of the State Judicial Administration of Ukraine. The territorial units of the Judicial Protection Service are formed: (1) as legal entities; or (2) as structural units of the central management body of the JPS that do not have the status of a legal entity. The maximum number of both the central governing body and the territorial units of the JPS is approved by the State Judicial Administration of Ukraine (Law of Ukraine No. 1402-VIII, 2016).

The Judicial Protection Service is accountable to the High Council of Justice and controlled by the State Judicial Administration of Ukraine. It is in accordance with paragraph 14 of Part 1 of Art. 152 of the Law of Ukraine "On judiciary and status of judges", the powers of the State Judicial Administration of Ukraine include control over the activities of the JPS (Law of Ukraine No. 1402-VIII, 2016).

As a general rule, the requirements of legislative acts of Ukraine are specified in the relevant by-laws and regulations. In 2019, the Regulation on the Judicial Protection Service was approved by a decision of the High Council of Justice. The approval of the Regulation on the Judicial Protection Service is referred to the competence of the High Council of Justice in accordance with Art. 3 of the Law of Ukraine "On the High Council of Justice" dated December 21, 2016 (Law of Ukraine No. 1798-VIII, 2016).

Many rules of the Law of Ukraine "On judiciary and status of judges" are duplicated in the Regulation on JPS. This applies to the very definition and tasks of the JPS, accountability and control, organizational structure, appointment and dismissal of the Chair of the JPS and his deputies, the maximum number of central control bodies and territorial divisions of the MTR, financing and the like. But in the Regulation on the MTR, the list of powers of this state body is much wider, unlike the one defined in the Law. In addition, the Regulation defines the main powers of the Chairman of the JPS and its deputies (Regulation on the Judicial Protection Service, 2019).

General provisions for the passing of the service in the JPS, including a list of special ranks of employees of the Judicial Protection Service, are enshrined in the Law of Ukraine "On judiciary and status of judges" and are specified in a separate Regulation on the performance of service by employees of the Judicial Protection Service, approved by the decision of the High Council of Justice dated April 4, 2019. According to the Regulation on the passing of the service, employees of the JPS employees are citizens, who were voluntarily accepted for service in the JPS, who took the Oath of the employee of the JPS and who were awarded special ranks in accordance with the Regulation. Employees belong to the JPS staff. The status of the employee is confirmed 
by an official certificate, the form and the order of issue of which are approved by the JPS Chairman. The staff grade is divided into junior, middle, and higher. Age limit for passing of the service:

1) employees who have special ranks of the junior grade of the Service are in the service until they reach 55 years old;

2) persons with special ranks of the middle and higher grade of the Service, depending on the special ranks assigned to them, are in the service until they reach the following age: up to Lieutenant Colonel of the Service - 55 years old; Colonel of the Service, General of the Service - 60 years old (Regulation on the passing of the service by the officers of the Judicial Protection Service, 2019).

JPS employees undergo vocational training consisting of: (1) primary vocational training; (2) postgraduate education; (3) job training. The appointment to the staff of the JPS (except for the appointment to equivalent or lower positions) is carried out according to the results of the competition conducted by the State Judicial Administration of Ukraine in accordance with the procedure established by the High Council of Justice. A contract is concluded for the passing of the service. It is a written agreement between the citizen of Ukraine and the state on whose behalf the Service acts, following the results of a competition to determine the legal relations between the parties during the passing of the service. The contract is the basis for issuing an order for admission of a person to the service. The dismissal of employees in the JPS is carried out:

(1) to the reserve of the Armed Forces (with military registration) - if fired persons have not reached the age limit for staying in the reserve and are fit for military service for health reasons;

(2) resignation - if fired persons reached the age limit for being in the reserve or recognized by the military medical commissions unsuitable for military service for health reasons, with the exception of military registration (Regulation on the passing of the service by the officers of the Judicial Protection Service, 2019).

Issues of cash support for employees of the JPS are regulated by the Resolution of the Cabinet of Ministers of Ukraine dated April 3, 2019. The Resolution approved the salary scheme for the posts of certain categories of JPS employees who occupy senior positions; schedule for tariff ranks and salary coefficients for JPS employees; the scheme of tariff ranks for the main typical positions of JPS employees; tariff coefficient scheme for special ranks of JPS employees; the size of the allowance for the length of service of JPS employees (Resolution of the Cabinet of Ministers of Ukraine No. 289, 2019).

Solution of the problem of further strengthening the system of protection of the court and participants in the judicial proceedings requires the study of factors of internal socio-economic environment which determine security efficiency and bringing them into line with the requirements of the current situation. One of the ways to understand in which direction it is necessary to look for changes of these factors follows from the second provision of the systems approach according to which any national judicial model is a closed complex socioprofessional system. The scheme of the systems approach can be represented in the form as it is shown in Fig. 1 , from which it follows that such a national judicial model functions successfully, effectively from the point of view of security, which satisfies the two conditions: (1) a judicial model must correspond to the external sociolegal environment; (2) economic and socio-legal systems must correspond to each other.

A number of researches on the protection of the court and litigants(Walkenhorst, Dihel, 2006) view mainly the evolution of socio-legal system as such due to change in organizational culture in the context of a legal cycle without paying attention to the "economic system - socio-legal system"relation. Such review of only a part of a protection system of participants in legal proceedings, on the one hand, narrows the scope of research and, on the other hand, does not allow to fully implement a systems approach. The method of solving this problem can be represented in the following way (Fig. 2). 


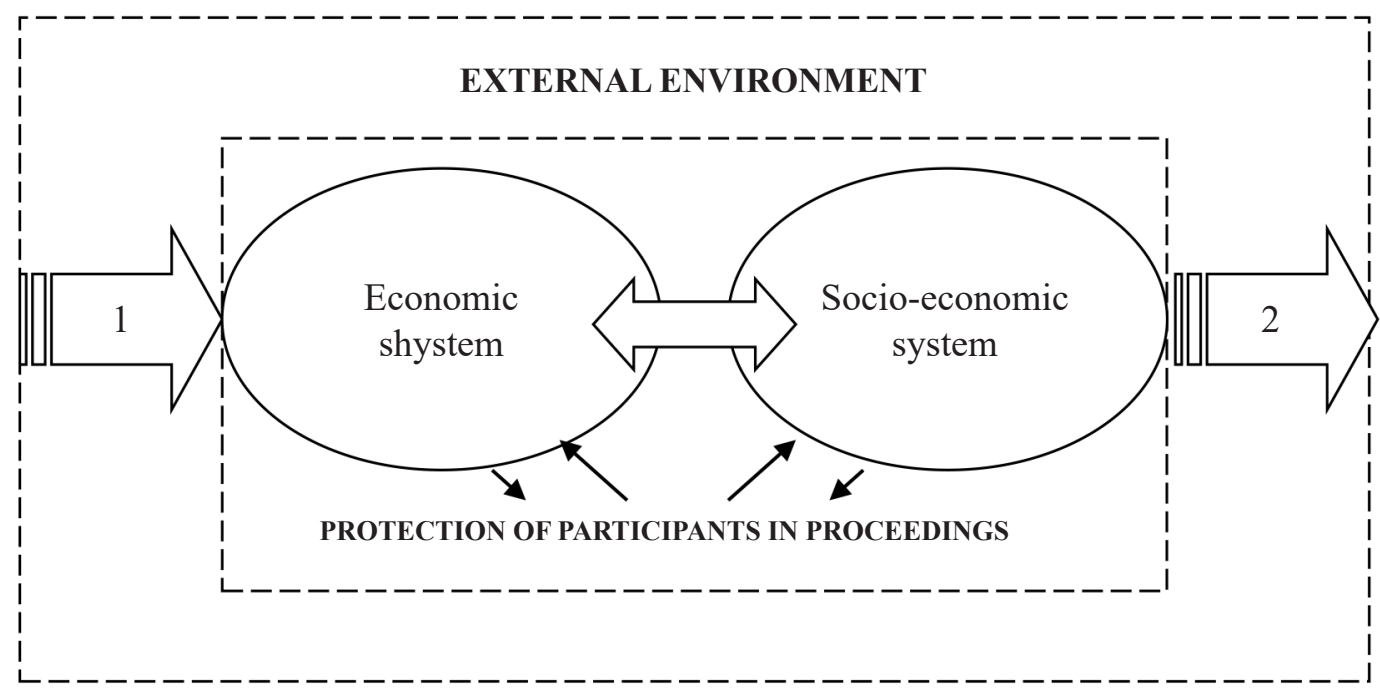

Figure 1. The scheme of a systems approach to the security models: 1 - inputs; 2 - outputs; $\rightarrow-$ influences

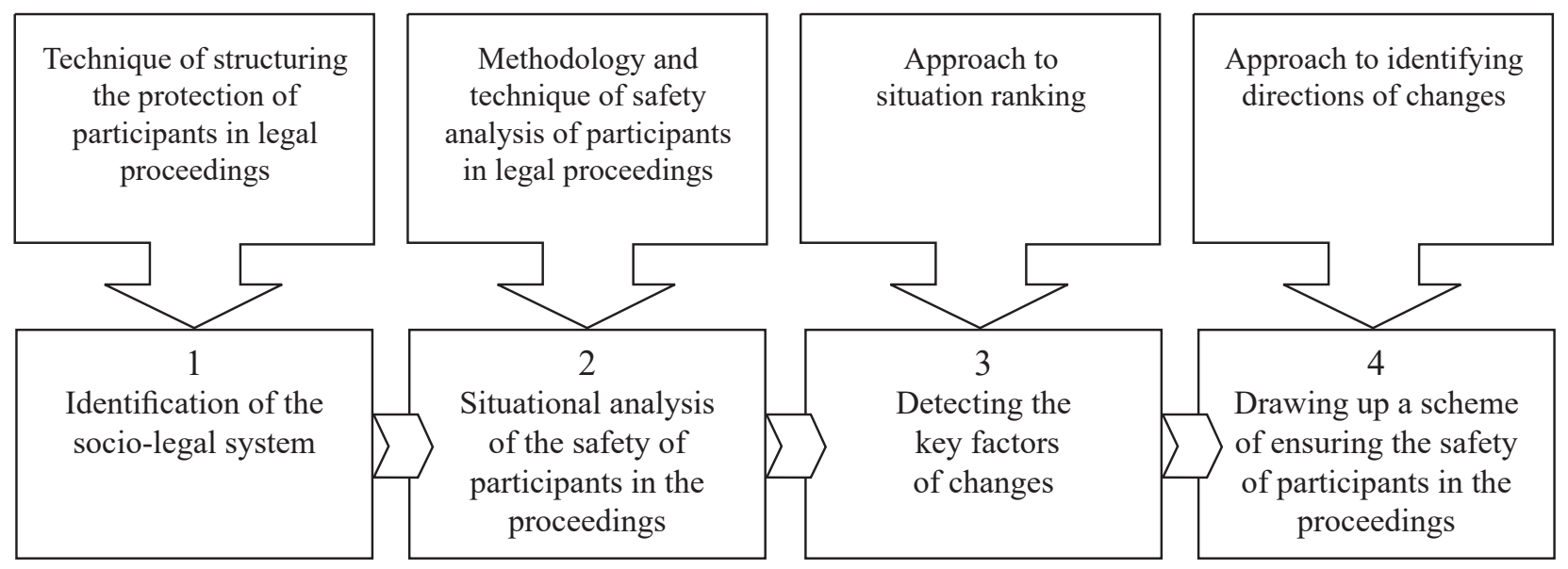

Figure 2. The scheme of application of the situational approach to management improvement of protection of participants in legal proceedings application

(1) first of all the social and economic systems should be identified, that is, one should define all their components and distinguish those elements which influence the quality of security management of participants in legal proceedings;

(2) then it is necessary to conduct situational analysis of the degree of conformity of the components of legal, social and economic systems to each other;

(3) the next stage is determination of the most important combinations of key pairs of elements of both systems which influence the effectiveness of security management of participants in the proceedings;

(4) on the basis of the conducted analysis, plans for changes in ensuring the safety of participants in legal proceedings are determined which bring them into line with the given system.

Itemization of the situational approach reviewed in Fig. 2 should be aimed at: development of a situational analysis method; classification of legal, social and economic systems of a country in relation to the task of security management of participants in legal proceedings, creation of methods for identifying the degree of compliance of the elements of the given systems and directions of organizational changes. The technique of situational analysis relating to the task which is reviewed in the article should be based on existing tools. Comprehensive situational analysis lies in diagnostics by various methods of organizational and managerial structure, management system and industrial and economic activity in order to identify the problems of security models in general. For this the authors offer the following algorithm (Fig. 3). 


\section{IDENTIFICATION OF THE SITUATION OF PROTECTION OF PARTICIPANTS IN LEGAL PROCEEDINGS}

- Audit of the security system of judges and participants in the proceedings.

- Identification and formulation of the problem.

- Expression of the problem using the terms of management.

- Setting the task for problem solution in the security area.

\section{1}

\section{ANALYSIS (STUDY) OF THE PROBLEM}

- Which factors are decisive? What will cause a change of one or more factors?

\section{DEFINING THE WAYS TO SOLVE THE PROBLEM}

- Formulation of the possible directions, ways, methods, means, options of solution to the problem.

- Creation of "the bank" of management techniques to solve the security problem.

\section{ANALYSIS OF CONSEQUENCES}

both positive and negative after application of this or that management technique to solve the problem.

\section{CHOOSING A TECHNIQUE (T)}

which, other conditions being equal, would have a maximum of positive consequences (results $-P$ ) with a minimum of negative consequences (expenses $-B): \Pi p_{i} \rightarrow(P / B)_{i} \rightarrow \max$.

\section{5}

\section{ANALYSIS OF DEFORMATION OF SECURITY SYSTEM OF PARTICIPANTS IN THE PROCEEDINGS}

- What changes in economic (or socio-legal) system will be caused by the application of the chosen method (technique) to solve the problem?

- To what extent do these changes cause a mismatch of the compliance of these systems with each other?

Figure 3. The process of comprehensive situational analysis implementation to diagnose the security of participants in the legal proceedings

Which is essentially a synthesis of a systematic approach, situational analysis and socio-economic approach to solving the problem of security of participants in the proceedings. Elementwise sutuational analysis lies in the study of each element of economic and socio-legal systems in order to identify the degree of compliance (nonconformity) with the current situation of ensuring the safety of participants in legal proceedings. Thus, elementwise situational analysis requires, firstly, a thorough development of a list of questions to be answered while studying each element. Secondly, since it is about a social system, the central element of which is a person, in this analysis, on the one hand, one should take into account the psychological aspects of socio-economic system functioning and, on the other hand, one should use sociological research.

To conduct an elementwise situational analysis "a gap" technique is used which helps to buid a martrix (Table 1). The results of comprehensive and elementwise analysis can be used as a basis for development of the plans for changes in the security system of participants in the proceedings. Before that it is necessary to perform a procedure- to create a methodical base for ranking organizational changes according to the level of importance for judges and participants in legal proceedings. The second consequence from socio-economic approach is used for this - "security model aging" which will be taken as a basic thesis of the analysis (Sheehan, (2005). 
Table 1. The scheme of "a gap" analysis in the elementwise situational analysis of the security of participants in the legal proceedings

\begin{tabular}{|l|c|c|c|}
\hline \multicolumn{1}{|c|}{ Element } & Current situation & Necessary condition & «Gap» \\
\hline Economic threats & - & & + \\
1. & + & - & - \\
2. & + & & - \\
\hline Social threats & + & & - \\
1. & & & \\
2. & & & \\
\hline Threats to life and health & & & \\
1. & & & \\
\hline 2. & & & \\
\hline
\end{tabular}

Review, systematization and generalization of researches on various aspects of ensuring the security of participants in the proceedings and a life cycle of a security model which currently exist allow to distinguish the key factors which are specific to different stages (Table 2).

Table 2. Characteristics of life cycle stages of a security model of participants in legal proceedings

\begin{tabular}{|c|l|l|}
\hline Stage & \multicolumn{1}{|c|}{ General characteristics } & \multicolumn{1}{c|}{ Key factors } \\
\hline «Birth» & $\begin{array}{l}\text { - Occupying a vacant niche } \\
\text { - Satisfaction of the interests of a judicial model }\end{array}$ & $\begin{array}{l}\text { - A small number of like-minded people } \\
\text { - Belief in success } \\
\text { - Risk preparedness } \\
\text { - Workability }\end{array}$ \\
\hline «Childhood» & $\begin{array}{l}\text { - Disproportionate to the growth of legal potential } \\
\text { for the development of a judicial model }\end{array}$ & $\begin{array}{l}\text { - Qualification of specialists in the protection of participants in } \\
\text { legal proceedings }\end{array}$ \\
\hline «Youth» & $\begin{array}{l}\text { - Transition from integrated to differentiated } \\
\text { security management }\end{array}$ & $\begin{array}{l}\text { - Intuition is replaced by calculations } \\
\text { - Usage of the known forms of analysis, planning, forecasting }\end{array}$ \\
\hline «Maturity» & $\begin{array}{l}\text { - Expansion of activities, differentiation, entry into } \\
\text { new areas, integration, diversification }\end{array}$ & $\begin{array}{l}\text { - Bureaucracy emerges } \\
\text { - Experienced administrators }\end{array}$ \\
\hline «Old age» & $\begin{array}{l}\text { - Things are getting worse } \\
\text { - A judiciary model must fight for survival }\end{array}$ & $\begin{array}{l}\text { - The victory of bureaucracy } \\
\text { - Deafness to new ideas }\end{array}$ \\
\hline
\end{tabular}

Such understanding of peculiarities of life cycle stages of a security model of participants in the proceedings allows us to conditionally determine a number of paired combinations of factor groups of internal environment which affect the safety of litigants, on the one hand, and key directions for improvement, on the other. For this purpose it is possible to build a matrix of key factors of integrated safety effectiveness of participants in legal proceedings the scheme of which is shown in Fig. 4.

\begin{tabular}{|c|c|c|c|}
\hline \multirow{2}{*}{ Protection system } & \multicolumn{3}{|c|}{ Legal system } \\
\cline { 2 - 4 } & Security potential & Values & Style \\
\hline Structure & I & II & III \\
\hline Systems & IV & V & VI \\
\hline Strategy & VII & VIII & IX \\
\hline
\end{tabular}

Figure 4. Matrix of key factors of integrated security of participants in the proceedings

The matrix is built on two axes. The abscissa axis contains system-forming factors of legal and social systems in a country. The ordinate axis contains the corresponding security factors for the judiciary and participants in legal proceedings. Each of six factors at any life cycle stage of integrated security of participants in the proceedings in some way influences the efficiency of protection but relative importance of such impact (Table 2) during a stage is different. The matrix allows to conditionally distinguish nine possible pairs of combinations of system-forming factors of integrated safety of participants. Ranking these combinations according to the degree of importance for different stages of a life cycle of a security model allows to identify the key directions of attention and concentration of efforts while creating changes in ensuring stable protection which 
can be done in a form of a separate matrix (Fig. 5). while constructing this matrix all the security models of participants in the legal proceedings conditionally are divided into the three groups according to the level of “oldness"(“youthfulness") - “young","mature","old”.

\begin{tabular}{|c|c|c|c|c|c|c|c|c|c|}
\hline \multirow{2}{*}{ Model } & \multicolumn{9}{|c|}{ Significance of system-forming factors(from Fig.4.) } \\
\cline { 2 - 10 } & I & II & III & IV & V & VI & VII & VIII & IX \\
\hline «Young» & 1 & & & & & & & & \\
\hline «Mature» & & & & & 1 & & & & \\
\hline «Old» & & & & & & & & & 1 \\
\hline
\end{tabular}

Figure 5. Matrix of ranking the factors of integrated security of participants in the proceedings

For the security models in the matrix it is possible to determine the rating of each of the nine pairs of factors. The most important (the most significant) combination is marked by number 1 (was put in the first place) which primarily defines economic efficiency. For "young"security models - this is definitely a combination of I (from the matrix, Fig. 4) "structure-security potential". Since the main task of "young"security models is to take hold in the legal environment then such issues as the organization of effective protection are of paramount importance and for this it is necessary to create and raise to an appropriate level the infrastructure and information work of those law enforcement and admiitrative staructures of a country which provide comprehensive protection of participants in legal proceedings. The term "system" in the most general sense means a set of formal and informal procedures on security models. Thus, the systems are connected to the performance of general security functions in the area of public management such as planning, organization, motivation and control, connecting functions- communication and decision-making, a number of special ones - accounting, analysis, regulation (Gaddis, 2005). To ensure that all these functions are effectively performed and for this it is necessary to solve the problem- to raise security models to the level of sustainable system at a state level.

There is a whole complex of information threats related to the problem of security state of judges and participants in legal proceedings among which the most destructive are the lack of identification of Ukraine in the global information space and the lack of a clear strategy for entering the global information society. The current condition of ensuring state information security requires the development of scientifically sound state policy and strategy in this area, defining the system of national values, vitally important interests of an individual, society and state, identifying external and internal threats to these interests, searching effective measures to ensure security in the information area.

Threats to information security - a set of conditions and factors which create a danger to the vitally important interests of judges and participants in the proceedings, society and a country in the information area. The main threats to information security are divided into three groups: a) threats of the impact of poor quality information(unreliable, false, misinformation) on an individual, society, country; b) threats of unauthorized and illegal influence of third parties on information about judges and their professional activities, information resources and information systems (their production, use); c) threats to the information rights and freedoms of an individual (the right to produce information, disseminate it, search, receive, transmit and use it; the intellectual property right to information including material one).

Considering the above noted, it can be argued that today the legal aspects of JPS in Ukraine have already been identified, that is, the necessary legislative framework for determining the legal status of this state body has already been formed. As to the organizational aspects of the formation of the state judicial protection body, then this process is still incomplete. The first court, where the JPS unit was operating, was the Seventh Administrative Court of Appeal in Vinnytsia. In some regions, JPS territorial departments are already operating, in particular, in Kyiv, Lviv, Ivano-Frankivsk, Odesa, Poltava, Sumy, Rivne, Ternopil, and Cherkasy regions, etc.

It should be noted that on November 6, 2019, the High Council of Justice held a working meeting on the development strategies of the Judicial Protection Service. During the working meeting, representatives of the High 
Council of Justice, the Verkhovna Rada of Ukraine, officials from the Canadian Department of Justice, the Canada Sheriffs Service and the Ukrainian-Canadian Judicial Reform Support Project in Ukraine discussed the strategy for the creation and development of the Judicial Protection Service.

The development strategy of the Judicial Protection Service covers the period up to 2022. Its key tasks as a state body in the justice system, created to ensure the protection and maintenance of public order in the courts, also include ending contempt of court, the protection of court buildings, bodies, and institutions of the justice system, the fulfillment of functions of the personal security of judges and members of their families, court apparatus workers, ensuring the security of participants of legal proceedings. The formation of JPS takes place in three stages:

1. The first stage (2019 - 2020) is the staffing of management bodies and units that will perform the tasks of protecting the Higher Anti-Corruption Court and other facilities, training and professional development of employees, protecting $100 \%$ of the facilities in the city of Kyiv, Kyiv and Vinnytsia regions, and courts of appeal and local courts in 16 regions of Ukraine. In 2020, it is planned to take 405 objects under protection of JPS.

2. The second stage (2021) - it is planned to ensure the protection of the remaining facilities (855), to understaff the management bodies and units of operational-sudden action and personal security of judges and members of their families.

3. The third stage (2022) is the completion of training programs, the understaffing of operational-sudden action units, the completion of the material and technical equipment of the Service (In 2021, the Judicial Protection Service will take care of all the organs and institutions of the justice system, 2020).

\section{Discussion}

Since 1997, special police units in the public security police structure (July 1997 - October 2003) have performed the functions of protecting the court, judges, and other participants of legal proceedings; the special unit of the judicial police "Hryfon" (November 2003 - October 2015); units of the National Guard of Ukraine and the National Police of Ukraine (November 2015 - May 2019).

Only in April 2019, in connection with the adoption of the Regulation on the Judicial Protection Service and the introduction of relevant amendments to legislative acts, the active process of creating this state body began. JPS territorial departments are already operating in some regions, in particular, in Kyiv, Lviv, Ivano-Frankivsk, Odesa, Poltava, Sumy, Rivne, Ternopil, and Cherkasy regions, etc. Competitions for occupying vacant posts in the JPS have been held repeatedly and according to the order of the Judicial Protection Service "On the announcement of the competition for the vacant posts in the Judicial Protection Service" dated March 6, 2020 under No. 120. The next selection is scheduled for March 25-26, 2020. However, in connection with the introduction of urgent measures by the National Security and Defense Council of Ukraine to ensure national security in an outbreak of acute respiratory illness COVID-19, as early as on March 17, 2020, the competitive selection of JPS employees was canceled on schedule. That is, the JPS formation process is still underway and not all facilities are protected, and it is unknown exactly how long this process can take.

Art. 10 of the Law of Ukraine "On the Higher Anti-Corruption Court", the legislator provides additional guarantees for the security of judges. In particular, it is indicated that the judge of the Supreme Anti-Corruption Court, and, if necessary, upon its application, its family members are provided with round-the-clock protection. According to the statement of the judge of the Supreme Anti-Corruption Court, round-the-clock protection of the judge's personal or service housing is carried out. The protection of the judge of the High Anti-Corruption Court, its family members, as well as the protection of the judge's home is ensured by JPS employees (Law of Ukraine No. 2447-VIII, 2018). However, how such a personal protection should be provided, or only for judges, or additionally for members of his family, is not spelled out in any document. The solution to this issue is possible through the development of an interdepartmental regulatory document jointly by the State Judicial Administration of Ukraine and the High Council of Justice in compliance with the requirements of the Law of Ukraine "On the Higher Anti-Corruption Court". 


\section{Conclusions}

The legal framework defining the legal status of the Judicial Protection Service of Ukraine, tasks, principles of activity, organizational structure of this state body, authority, monetary and social security of employees, etc contained in a number of legal acts. Among them: the Constitution of Ukraine; Laws of Ukraine "On judiciary and status of judges", "On state protection of court employees and law enforcement bodies", "On ensuring the safety of persons participating in criminal proceedings"; Regulation on the Judicial Protection Service; Regulation on the performance of the service by members of the Judicial Protection Service; Decree of the Cabinet of Ministers of Ukraine "On the monetary allowance of employees of the Judicial Protection Service".

It is important to note that to date, the formation of the Judicial Protection Service of Ukraine has not yet been completed. In general, the Development Strategy of the Judicial Protection Service covers the period until 2022, which involves three stages: (1) the first stage (2019 - 2020) - the staffing of management bodies and units that will perform the tasks of protecting the Higher Anti-Corruption Court and other facilities, training and staff development, protecting 405 facilities; (2) the second stage (2021) - it is planned to ensure the protection of the rest of the facilities (855), to understaff the management bodies and units of the operational-sudden action and personal safety of judges and members of their families; (3) the third stage (2022) is the completion of training programs, the understaffing of units of operational-sudden action, the completion of the material and technical equipment of the Service.

\section{References}

About the European Committee on Legal Co-operation (CDCJ). The official website of The European Committee on Legal Co-operation (CDCJ). URL: https://www.coe.int/en/web/cdcj/european-committee-legal-cooperation

Chehabeddine, M., Tvaronavičienė, M. (2020). Securing regional development. Insights into Regional Development, $2(1), 430-442$. http://doi.org/10.9770/IRD.2020.2.1(3)

Constitution of Ukraine (1996). As amended up to Act of January 01, 2020. URL: https://zakon.rada.gov.ua/laws/show/254\%D0\%BA/96$\% \mathrm{D} 0 \% \mathrm{~B} 2 \% \mathrm{D} 1 \% 80$

Convention for the Protection of Human Rights and Fundamental Freedoms (1950). URL: https://www.coe.int/en/web/conventions/ full-list/-/conventions/treaty/005

In 2021, the Judicial Protection Service will take care of all the organs and institutions of the justice system (2020). The official website of The Judiciary of Ukraine. URL: https://cv.arbitr.gov.ua/press/news/818999/

Judicial independence and impartiality. The official website of The European Committee on Legal Co-operation (CDCJ). URL: https:// www.coe.int/en/web/cdcj/judicial-independence-and-impartiality

Kordík M. Kurilovská, L. (2019). Content of a IntraGroup Compliance Agreement as a risk mitigating factor. Entrepreneurship and Sustainability Issues, 6(3), 1095-1104. http://doi.org/10.9770/jesi.2019.6.3(10)

Kuril, J. (2018). Public administration for safe and secure environment: case of Slovak Republic, Entrepreneurship and Sustainability Issues 5(3): 493-501. https://doi.org/10.9770/jesi.2018.5.3(6)

Law of Ukraine № 1402-VIII On the judiciary and the status of judges (2016). As amended up to Act of February 18, 2020. URL: https:// zakon.rada.gov.ua/laws/show/1402-19

Law of Ukraine № 1798-VIII On the High Council of Justice (2016). As amended up to Act of November 28, 2019. URL: https://zakon. rada.gov.ua/laws/show/1798-19

Law of Ukraine № 2447-VIII on the Supreme Anticorruption Court (2018). As amended up to Act of November 28, 2019. URL: https:// zakon.rada.gov.ua/laws/show/2447-19

Law of Ukraine № 2509-VIII On Amendments to the Law of Ukraine On Judiciary and Status of Judges in connection with the adoption of the Law of Ukraine On the Supreme Anticorruption Court (2018). URL: https://zakon.rada.gov.ua/laws/show/2509-19

Law of Ukraine № 3781-XII On state protection of court employees and law enforcement agencies (1993).As amended up to Act of 
August 05, 2018. URL: https://zakon.rada.gov.ua/laws/show/3781-12

Law of Ukraine № 3782-XII On ensuring the safety of persons involved in criminal proceedings (1993). As amended up to Act of January 01, 2020. URL: https://zakon.rada.gov.ua/laws/show/3782-12

Law of Ukraine № 398/95-VR On the Accession of Ukraine to the Charter of the Council of Europe (1995). URL: https://zakon.rada. gov.ua/laws/show/398/95-\%D0\%B2\%D1\%80

Law of Ukraine № 580-VIII On the National Police (2015). As amended up to Act of February 02, 2020. URL: https://zakon.rada.gov. ua/laws/show/580-19

Lincényi, M., Čársky, J. (2020). Policy trusts in public policy in the Slovak Republic. Insights into Regional Development, 2(1), 456468. http://doi.org/10.9770/IRD.2020.2.1(5)

Order of the Ministry of Internal Affairs of Ukraine № 1352 Approving the Provisional Procedure for Ensuring the Protection of Courts, Bodies and Institutions of the Justice System, as well as Maintaining Public Order in them (2016). Retrieved from https://mvs.gov.ua/ ua/pages/Nakaz_1352_vid_26122016_Pro_zatverdzhennya_Timchasovogo_poryadku_zabezpechennya_ohoroni_sudiv_organiv_ta_ ustanov_sistemi_pravosuddya_a_takozh_pidtrimannya_gromadskogo_poryadku_v_nih.htm

Order of the Ministry of Internal Affairs of Ukraine № 467 On the establishment of special police units to ensure the safety of court employees, law enforcement agencies, persons involved in criminal proceedings, their families and close relatives (1997). URL: https:// zakon.rada.gov.ua/laws/show/z0341-97

Plan of action on strengthening judicial independence and impartiality (2016). URL: https://rm.coe.int/1680700125

Prause, G., Tuisk, T., Olaniyi. (2019). Between Sustainability, Social Cohesion and Security. Regional Development in North-Eastern Estonia. Entrepreneurship and Sustainability Issues, 6(3), 1135-1154. http://doi.org/10.9770/jesi.2019.6.3(13)

Recommendation CM/Rec(2010)12 on judges: independence, efficiency and responsibilities (2010). URL: https://www.icj.org/wpcontent/uploads/2014/06/CMRec201012E.pdf

Regulation on the Judicial Protection Service (2019). As amended up to Act of December 03, 2019. URL: https://zakon.rada.gov.ua/ rada/show/v1051910-19

Regulation on the passing of the service by the officers of the Judicial Protection Service (2019). URL: https://zakon.rada.gov.ua/rada/ show/v1051910-19

Regulations on the special unit of the judicial police «Hryfon» (2003). URL: https://zakon.rada.gov.ua/laws/show/z1139-03

Resolution of the Cabinet of Ministers of Ukraine № 289 On financial support of the Judicial Protection Service staff (2019). URL: https://zakon.rada.gov.ua/laws/show/289-2019-\%D0\%BF

Resolution of the Cabinet of Ministers of Ukraine № 906 On ensuring the protection of courts, other bodies and institutions of the judicial system, as well as institutions of judicial expertise (2015). URL: https://zakon.rada.gov.ua/laws/show/906-2015-\%D0\%BF

Savilova, K. (2019). How the experience of Canadian sheriffs can help build a Judicial Protection Service in Ukraine. Zakon i biznes. URL: https://zib.com.ua/ua/138721-yak_dosvid_kanadskih_sherifiv_mozhe_dopomogti_pobudovi_sso_v.html

Sitdikova, L.B., Starodumova, S.J. (2019). Corporate agreement as a means of providing security in the course of entrepreneurship development. Entrepreneurship and Sustainability Issues, 7(1), 324-335. http://doi.org/10.9770/jesi.2019.7.1(24)

Stefaniuk, T. (2020). Training in shaping employee information security awareness. Entrepreneurship and Sustainability Issues, 7(3), 1832-1846. https://doi.org/10.9770/jesi.2020.7.3(26)

Support to the judicial reform in Ukraine. The official website of The European Committee on Legal Co-operation (CDCJ). URL: https://www.coe.int/en/web/cdcj/-support-to-the-judicial-reform-in-ukraine

Temporary order of ensuring the protection of the courts, authorities and institutions of the justice system, as well as maintaining public order in them (2016). URL: https://lva.court.gov.ua/sud1390/poryadok/

The official website of the Canadian County Sheriff's Office (CCSO). URL: https://www.ccsheriff.net/

The official website of the Los Angeles County Sheriff's Department. URL: http://www.lasd.org

The official website of the National Sheriffs' Association (NSA). URL: https://www.sheriffs.org/about-nsa 
Vadym KOLOMIIETS, Doctor of Law, specialist of the Educational-scientific Institute of distance learning and advanced training Dnipropetrovsk State University of Internal Affairs

ORCID ID: orcid.org/0000-0001-5678-675X

Tetiana LUKIANENKO, Lecturer of the General Legal Disciplines Chair of Law Department of Dnipropetrovsk State University of Internal Affairs

ORCID ID: orcid.org/0000-0003-2148-418X

Daria LAZAREVA, Candidate of Juridical Science, Head of Doctoral and Graduate Department in Dnipropetrovsk University of internal Affairs

ORCID ID: orcid.org/0000-0002-5987-6643

Nana BAKAIANOVA, Head of the Department of Judicial, Law Enforcement Authorities and Advocacy, National University “Odessa Law Academy"

ORCID ID: orcid.org/0000-0002-7669-0576

Oksana KADENKO, member of Bar Council of Ukraine, postgraduate of the Department of Judicial, Law Enforcement Authorities and Advocacy, National University "Odessa Law Academy"

ORCID ID: orcid.org/0000-0002-3094-3224 